\title{
Article \\ Catalyst and Elemental Analysis Involving Biodiesel from Various Feedstocks
}

\author{
Ines Simbi ${ }^{1}$, Uyiosa Osagie Aigbe ${ }^{2}$, Oluwaseun Oyekola ${ }^{1}$ (D) and Otolorin Adelaja Osibote ${ }^{2, *(D)}$ \\ 1 Department of Chemical Engineering, Faculty of Engineering and the Built Environment, Cape Peninsula \\ University of Technology, P.O. Box 1906, Bellville 7535, South Africa; Inesimbi09@gmail.com (I.S.); \\ OyekolaS@cput.ac.za (O.O.) \\ 2 Department of Mathematics and Physics, Faculty of Applied Sciences, Cape Peninsula University of \\ Technology, P.O. Box 652, Cape Town 8000, South Africa; AigbeU@cput.ac.za \\ * Correspondence: osiboteA@cput.ac.za; Tel.: +27-21-460-9092
}

Citation: Simbi, I.; Aigbe, U.O.; Oyekola, O.; Osibote, O.A. Catalyst and Elemental Analysis Involving Biodiesel from Various Feedstocks. Catalysts 2021, 11, 971. https:// doi.org/10.3390/catal11080971

Academic Editor: S David Jackson

Received: 14 July 2021

Accepted: 11 August 2021

Published: 14 August 2021

Publisher's Note: MDPI stays neutral with regard to jurisdictional claims in published maps and institutional affiliations.

Copyright: () 2021 by the authors. Licensee MDPI, Basel, Switzerland. This article is an open access article distributed under the terms and conditions of the Creative Commons Attribution (CC BY) license (https:// creativecommons.org/licenses/by/ $4.0 /)$.

\begin{abstract}
The world is currently faced with the depletion of fossil fuel energy sources and their use is associated with environmental pollution. This has triggered the need to seek alternative energy sources that are renewable, sustainable and environmentally benign. Biodiesel, an alternative fuel of interest, is obtainable from biomass feedstocks. In existing biodiesel fuel, there are concerns that it is a contaminant due to its elemental contents, which over time also affect its quality. This study aimed to investigate the influence of a bifunctional catalyst on the conversion of free fatty acids and the elemental composition of biodiesel obtained from waste oils of sunflower and palm feedstocks. The synthesised catalyst was characterised using BET, XRD, FTIR and SEM while ICP-OES and Rancimat were used for elemental contents and oxidation in feedstocks and biodiesels. The effect of $\mathrm{Cu}, \mathrm{Zn}$ and Fe metals on the stability of synthesised biodiesel was further studied. The catalyst showed characteristics of bifunctionality with improved textural properties necessary for the conversion of high free fatty acids feedstocks to biodiesel, despite increasing Ca content within the produced biodiesel. Sunflower biodiesel showed superior fuel quality, although palm biodiesel had more oxidation stability. An increase in the concentration of metals decreased the induction period, with $\mathrm{Cu}$ and Fe being more effective than $\mathrm{Zn}$ metal.
\end{abstract}

Keywords: bifunctional catalyst; biodiesel; elemental content; degradation; metals; oxidation stability; transesterification; waste cooking oils

\section{Introduction}

Global primary energy demand is set to experience an annual increase of $1.46 \%$ from 2009 to 2035 [1]. This is not surprising, as industrialisation has grown significantly with a rise in the global population to 7.3 billion in 2015 , which is projected to further grow to 9.2 billion in 2040 [2]. The enormous use of fossil fuels has put the environment and human health at risk [3,4], with energy utilisation especially high in the transportation sector, which is expected to make up about $63 \%$ of total global fuel consumption from 2010 to $2040[5,6]$.

In 2008, it was reported that the transportation sector contributed to about $23 \%$ of total $\mathrm{CO}_{2}$ emissions globally [7,8], with $73 \%$ of this contribution made by road transport [9], while the contribution from fuel combustion increases by $1.6 \%$ per year [1]. This will lead to severe ecological impacts, namely air and noise pollution, an increase in global surface temperatures (excess of $6^{\circ} \mathrm{C}$ ), changes in rainfall patterns and subsequently extreme weather events [1,10-12].

Apart from the potential exhaustion of petroleum reserves over time [13], fuel prices have increased [14] due to oil reserves being concentrated in specific regions in the world [15], giving rise to some political conflicts. Therefore, a more significant sustainable movement led by advancement towards environmental conservation, a feasible economy 
and equity has prompted a search for substitutes for fossil fuels. The substitute must be eco-friendly and a viable energy-generating fuel [16].

The quest for green energy fuel led to the discovery of biodiesel, which is chemically defined as monoalkyl esters of long-chained fatty acids, having physicochemical characteristics similar to that found in petroleum diesel [17]. This fuel is believed to release on average $48 \%$ less carbon monoxide, $47 \%$ less particulate material and $67 \%$ less hydrocarbon than petroleum diesel [18]. However, producing biodiesel has cost implications attached to it, since it can be synthesised from vegetable oils and animal fats through chemical processes such as transesterification [19]. The raw materials account for about 70-95\% of its production costs [20]. Therefore, to minimise costs, the use of waste cooking oils rather than food-grade oils is suggested for economic efficiency [21] and pollution reduction resulting from improper waste oil disposal to the environment [22].

Waste oils are mainly composed of free fatty acids (FFA), which are highly unsaturated [23] and would require acid and base-catalysed reaction to convert the high FFA feedstocks into fatty acid methyl esters [5]. This is despite the fact that heterogeneous catalysts are easily separated after the transesterification reaction [24], which promotes their reusability [25]. They also can overcome saponification, in contrast to homogeneous catalysts [26]. However, heterogeneous catalysts have mass transfer limitations with a reduced rate of reaction as a result of the formation of three phases with oil and alcohol [5], and the leaching of active phases may occur in the reaction medium [27]. To overcome this diffusion problem structurally, promoting the catalyst can be performed [28]. This improved structure will stimulate a catalyst with enhanced stability against dissolution by forming a bifunctional catalyst with a potential for increased activity and selectivity [29], along with enhanced stability compared to the monometallic counterpart due to more active sites [30], which can esterify and transesterify feedstock of high FFA.

It is believed that metals found in biodiesel are brought in during syntheses via the use of hard water during washing or by the catalyst used [31,32], as well as in the storage and transport process [33]. Chaves et al. [34] reported that they can exist within feedstocks due to soil types and fertilisers used, along with hydrological conditions according to geographical origins $[35,36]$. These metals may cause many mechanical problems within engines if their contents are excessive [35]. Some of the issues caused by the presence of metals are the corrosion of certain engine parts and the deactivation of catalysts, leading to environmental harm [32,37]. A study conducted by Waynick [38] showed that the presence of $\mathrm{Cu}, \mathrm{Fe}, \mathrm{Ni}, \mathrm{Sn}$ and $\mathrm{Cu}-\mathrm{Zn}$ (a copper-rich alloy) metals can increase the oxidisation of fatty oils $[8,38]$. They reported that in biodiesel, $\mathrm{Cu}$ reduces oxidation stability more than Fe and $\mathrm{Ni}$, while $\mathrm{Fe}$ is an effective hydroperoxide decomposer. Copper is the most corrosive element in palm biodiesel [39]. Meanwhile, $\mathrm{Al}$ and $\mathrm{Sn}$ are characterised by low catalytic activity and $\mathrm{Cu}, \mathrm{Fe}, \mathrm{Ca}$ and $\mathrm{Mg}$ were found to accelerate oxidation reaction [35,40]. Some metals such as phosphorus $(\mathrm{P})$ can poison the catalytic converters, causing emissions of $\mathrm{CO}, \mathrm{CO}_{2}$ and $\mathrm{SO}_{2}$ [41]. This subsequently has an effect on human health through emission particulate matters of oxides, nitrates, sulphates or peroxides [42], and in combination with polluted air can also migrate into the soil and water table [43]. Even though $\mathrm{Cd}$ and $\mathrm{Zn}$ can partially be lost by volatilisation [44], the most concerning elements are catalyst residues and sulphur [40].

Corrosion within metallic tanks is due to microorganism growth within tanks, which leads to degradation of the fuel. Therefore, as the fuel is stored over time, there is a necessity in evaluating the effect of metals that come in contact with the fuel [39]. This study presents the production of a $\mathrm{CaO} / \mathrm{Al}_{2} \mathrm{O}_{3}$ catalyst using the wet impregnation method using a ratio of $75 \%$ of $\mathrm{CaO}$ and $25 \%$ of $\mathrm{Al}_{2} \mathrm{O}_{3}$ (calcined), which was characterised using FTIR, SEM, $\mathrm{XRD}$ and $\mathrm{BET}$. The catalyst was used in transesterification biodiesel from waste cooking oils of palm and sunflower. Evaluation of the elemental contents from feedstocks to biodiesel produced was performed by ICP-OES and fuel properties were characterised by Density Meter, Flash Tester, Viscometer and FTIR spectrometer. Additionally, the effect of $\mathrm{Cu}, \mathrm{Zn}$ and Fe on oxidation stability of the produced biodiesels was also studied. 


\section{Results}

This section gives an overview of the bifunctional $\mathrm{CaO} / \mathrm{AI}_{2} \mathrm{O}_{3}$ catalyst synthesised using the wet impregnation method, as well as the characterisation of the synthesised catalyst using SEM, XRD, FTIR and BET to determine the surface morphology, crystalline structure, functional groups and surface area, pore volume and diameter. Also discussed in this section is the fatty acids content within each feedstock estimation and the fuel properties determined using the gas chromatography (GC), viscometer, density meter, flash tester, color-indicator titrator and FTIR.

\subsection{Bifunctional Catalyst Characterisation}

The FTIR spectrum of $\mathrm{CaO}, \mathrm{Al}_{2} \mathrm{O}_{3}$ and $\mathrm{CaO} / \mathrm{Al}_{2} \mathrm{O}_{3}$ catalyst is shown in Figure 1 , with absorption bands in the range of $400-4000 \mathrm{~cm}^{-1}$. Figure 1a shows all characteristic peaks of $\mathrm{CaO}$ with a broad $\mathrm{CO}_{3}$ stretch at $1409.32 \mathrm{~cm}^{-1}$ and a smaller $\mathrm{CaO}$ band [45], while the presence of water molecules in the un-calcined catalyst was observed with a strong hydroxy (H-O) band appearing at $3640.79 \mathrm{~cm}^{-1}$ [46]. Intense peaks at $636.06 \mathrm{~cm}^{-1}, 554.55 \mathrm{~cm}^{-1}$ and $485.48 \mathrm{~cm}^{-1}$ are presented in Figure 1b, with dominancy of Al-O normally found in the region of $1000-400 \mathrm{~cm}^{-1}$ [47]. The synthesised $\mathrm{CaO} / \mathrm{Al}_{2} \mathrm{O}_{3}$ catalyst was confirmed by the co-existing of $\mathrm{Ca}-\mathrm{O}$ and $\mathrm{Al}-\mathrm{O}$ within the $\mathrm{CaO} / \mathrm{Al}_{2} \mathrm{O}_{3}$ catalyst as shown in Figure $1 \mathrm{c}$, by the presence of $\mathrm{CaO}$ absorption bands at $875 \mathrm{~cm}^{-1}$ and $713 \mathrm{~cm}^{-1}$ correspondings to $\mathrm{C}-\mathrm{O}$ and $\mathrm{Ca}-\mathrm{O}$ bonding and by a broader $\mathrm{CaCO}_{3}$ band at $1469.80 \mathrm{~cm}^{-1}$. The $\mathrm{H}$-bonded hydroxyl group appeared due to moisture and the presence of $\mathrm{CO}_{2}$ [48]. Furthermore, Table 1 re-affirms these compositions within the synthesised catalyst.
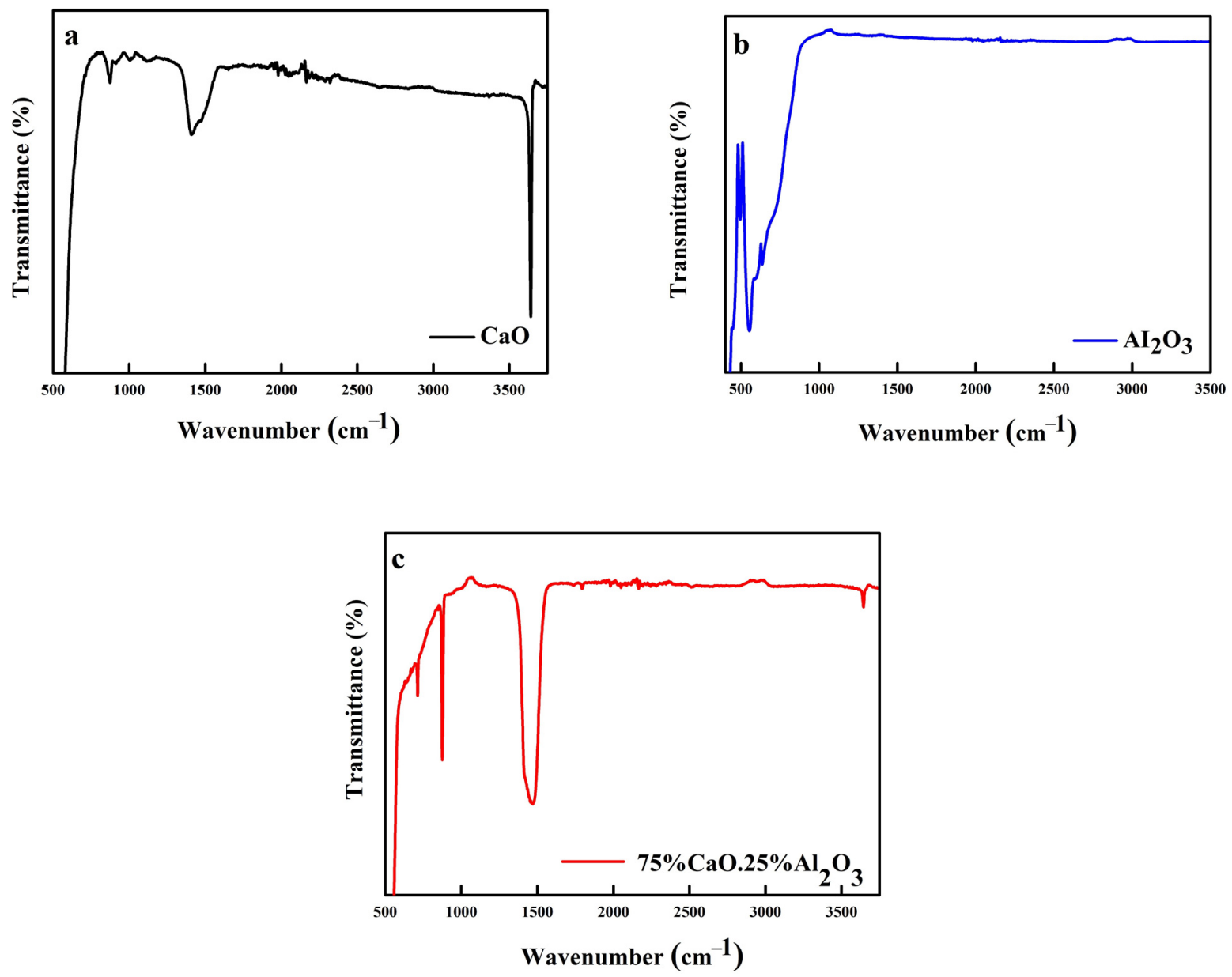

Figure 1. FTIR curves for the (a) $\mathrm{CaO},(\mathbf{b}) \mathrm{Al}_{2} \mathrm{O}_{3}$ and (c) synthesised $\mathrm{CaO} / \mathrm{Al}_{2} \mathrm{O}_{3}$ catalyst. 
Table 1. Composition of compounds within the catalyst.

\begin{tabular}{cccc}
\hline Material & Compound & Formula & Composition (\%) \\
\hline \multirow{2}{*}{$\mathrm{CaO}$} & Portlandite & $\mathrm{Ca}(\mathrm{OH})_{2}$ & 50 \\
& Lime & $\mathrm{CaO}$ & 50 \\
\hline \multirow{2}{*}{$\mathrm{Al}_{2} \mathrm{O}_{3}$} & Aluminium Oxide & $\mathrm{Al}_{2} \mathrm{O}_{3}$ & 0.69 \\
& Oxonium Aluminium Oxide & $\mathrm{H}_{3} \mathrm{O}_{2} \mathrm{Al}_{22} \mathrm{O}_{34}$ & 75 \\
\hline \multirow{2}{*}{$75 \mathrm{CaO}-25 \mathrm{Al}_{2} \mathrm{O}_{3}$} & Portlandite & $\mathrm{Ca}(\mathrm{OH})_{2}$ & 92.08 \\
& Lime & $\mathrm{CaO}$ & 63.79 \\
& Calcite & $\mathrm{CaCO}_{3}$ & 8.73 \\
& Aluminium Oxide & $\mathrm{Al}_{2} \mathrm{O}_{3}$ & 22.92 \\
\hline
\end{tabular}

The external morphological characteristics of $\mathrm{Al}_{2} \mathrm{O}_{3}$ and synthesised $\mathrm{CaO} / \mathrm{Al}_{2} \mathrm{O}_{3}$ catalyst after calcination at $475{ }^{\circ} \mathrm{C}$ were studied by SEM. Figure 2a,b illustrates the morphology of commercial $\mathrm{Al}_{2} \mathrm{O}_{3}$ particles appearing as crystals of corundum, normally found to promote densification of corundum shape-like composites which help in enhancing performance [49]. After thermal treatment with high temperatures for $5 \mathrm{~h}(\mathrm{hr})$ and impregnation of $\mathrm{CaO}$, a modification of $\mathrm{Al}_{2} \mathrm{O}_{3}$ into irregularly shaped clusters due to the breakage of large particles into smaller pieces [50], with the intensification of $\mathrm{CaO}$ particle agglomeration on the support, can be observed in Figure 2. This is due to the huge percentage of metal oxide which normally has an irregular shape even after thermal treatment [25], and the presence of impurities and unconverted $\mathrm{Ca}(\mathrm{OH})_{2}$ [51]. Micrographs were in agreement with the results found in Table 2, where the supported oxide in Figure 2c,d showed the increased surface area and increased pore size distribution as was also reported by Young et al. [52], which increases activity due to the formation of more active sites on the surface area and has an effect on the reaction rates and selectivity [53].

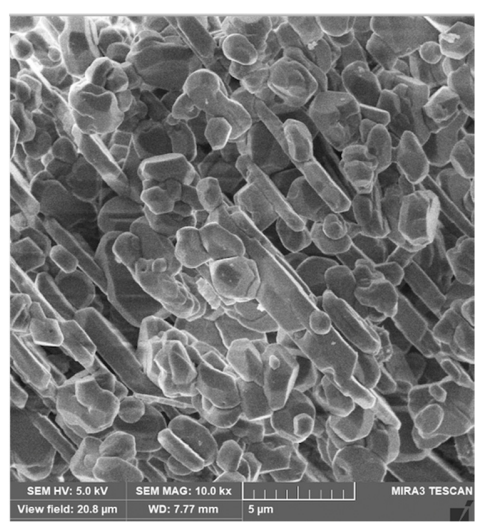

(a)

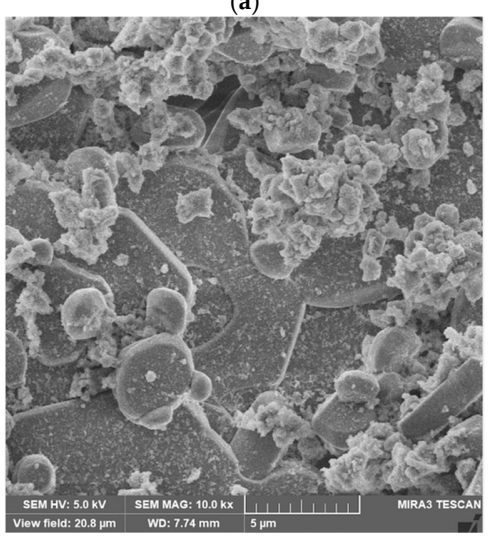

(c)

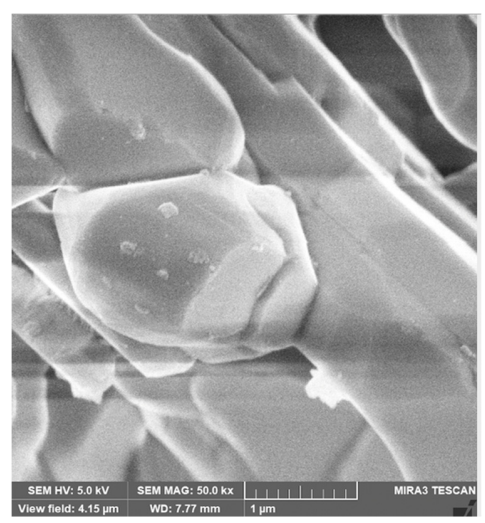

(b)

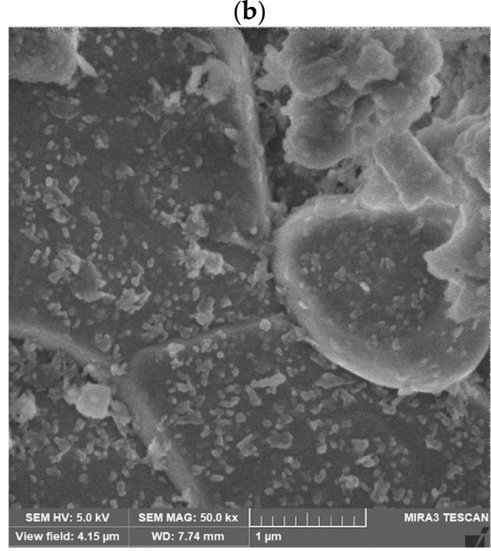

(d)

Figure 2. Scanning electron microscopy (SEM) images of $(\mathbf{a}, \mathbf{b})$ Reference $\mathrm{Al}_{2} \mathrm{O}_{3}$ and (c,d) $75 \% \mathrm{CaO} / 25 \% \mathrm{Al}_{2} \mathrm{O}_{3}$. 
Table 2. Textural properties and surface area analysis.

\begin{tabular}{cccc}
\hline Catalyst & BET Surface Area $\left(\mathbf{m}^{2} / \mathbf{g}\right)$ & Pore Volume $\left(\mathbf{c m}^{3} / \mathbf{g}\right)$ & Pore Diameter $(\mathbf{n m})$ \\
\hline $\mathrm{Al}_{2} \mathrm{O}_{3}$ & 0.6239 & 0.000857 & 5.9147 \\
$75 \% \mathrm{CaO} / 25 \% \mathrm{Al}_{2} \mathrm{O}_{3}$ & 13.0006 & 0.079732 & 24.0371 \\
\hline
\end{tabular}

Figure 3 displays the $\mathrm{XRD}$ patterns of $\mathrm{CaO}$ and $\mathrm{Al}_{2} \mathrm{O}_{3}$ material prior to calcination and after the catalyst was synthesised. The results confirmed the characteristic peaks of $2 \theta$ ranging from $18^{\circ}$ to $80^{\circ}$. Table 1 shows that there was an even distribution of lime and portlandite for $\mathrm{CaO}$ while in Figure $3 \mathrm{~b}, \mathrm{Al}_{2} \mathrm{O}_{3}$ support can be seen to have appeared at intensified peaks of $25.55^{\circ}, 35.11^{\circ}, 43.30^{\circ}, 52.49^{\circ}, 57.43^{\circ}$ and $68.13^{\circ}$, These peaks reaffirmed the presence of rhombohedral $\mathrm{Al}_{2} \mathrm{O}_{3}$. Face-centered cubic $\mathrm{CaO}$ peak was found at $32.20^{\circ}$, $37.35^{\circ}, 54^{\circ}$ and $64.15^{\circ}$ As seen in Figure $3 a$, these peaks correspond to the crystal planes of $\mathrm{CaO}$ and its cubic shape $[54,55]$. The $\mathrm{CaO} / \mathrm{Al}_{2} \mathrm{O}_{3}$ pattern also indicated small peaks of rhombohedral $\mathrm{CaCO}_{3}$, hexagonal $\mathrm{Ca}(\mathrm{OH})_{2}$ and $\left(\mathrm{H}_{3} \mathrm{O}\right)_{2} \mathrm{Al}_{22} \mathrm{O}_{34}$, which were spread through with intense peaks of $\mathrm{Ca}(\mathrm{OH}), \mathrm{CaO}$ and $\mathrm{Al}_{2} \mathrm{O}_{3}$ in that order.
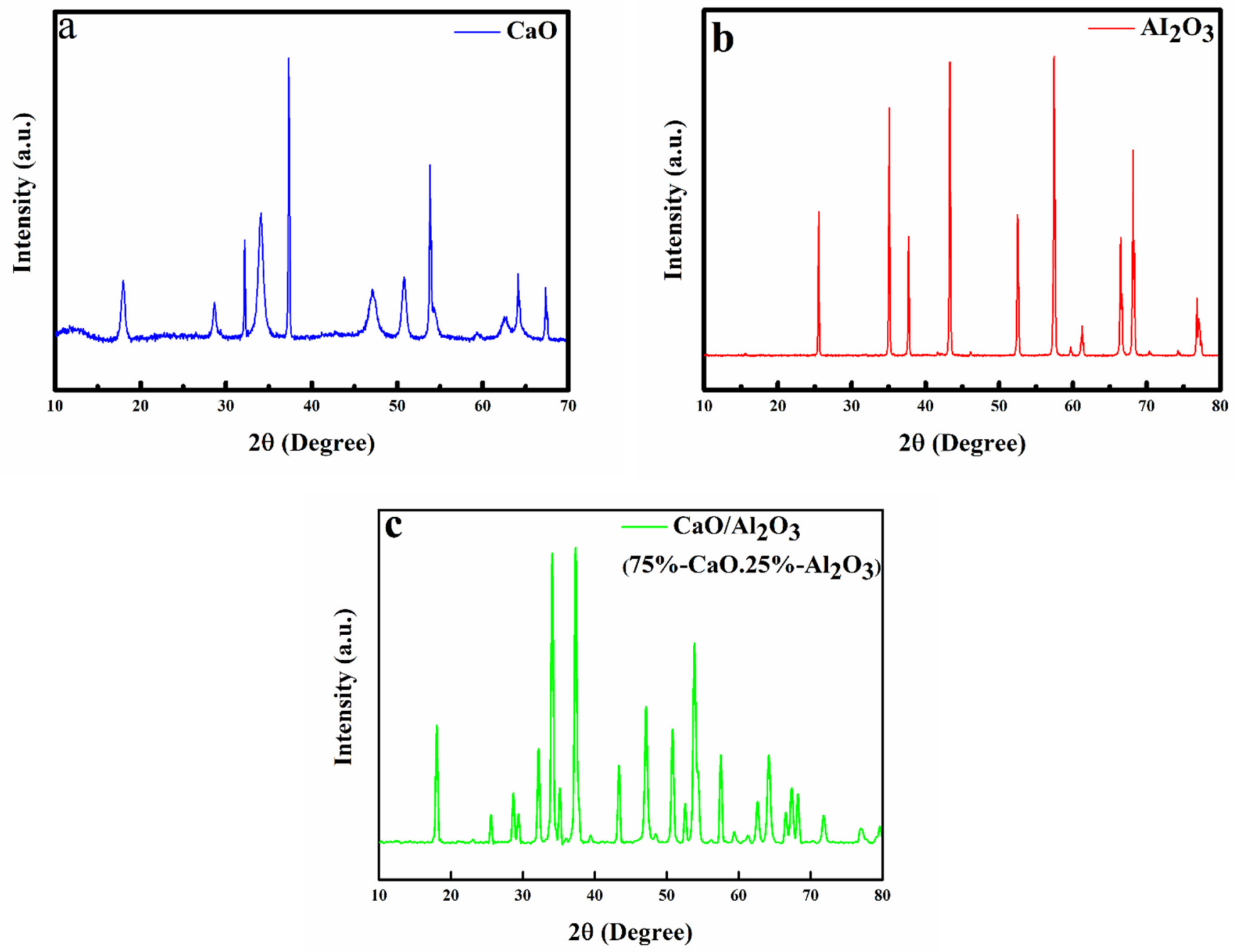

Figure 3. $\mathrm{XRD}$ patterns of (a) $\mathrm{CaO},(\mathbf{b}) \mathrm{Al}_{2} \mathrm{O}_{3}$ and (c) $\mathrm{CaO} / \mathrm{Al}_{2} \mathrm{O}_{3}$.

The specific surface area and pore volume were determined by the nitrogen adsorptiondesorption technique summarised in Table 2, using Brunauer-Emmett-Teller (BET). The nitrogen isotherms recorded in Figure 4 for $\mathrm{CaO} / \mathrm{Al}_{2} \mathrm{O}_{3}$ showed hysteresis over the relative pressure. The $\mathrm{N}_{2}$ isotherms exhibited a typical s-shaped behavior of type IV with a type H1 
desorption hysteresis loop as categorised by IUPAC [56-58], indicating a potential presence of relatively wide cylindrical pores $[59,60]$, which shows characteristics of a mesoporous material $[61,62]$.

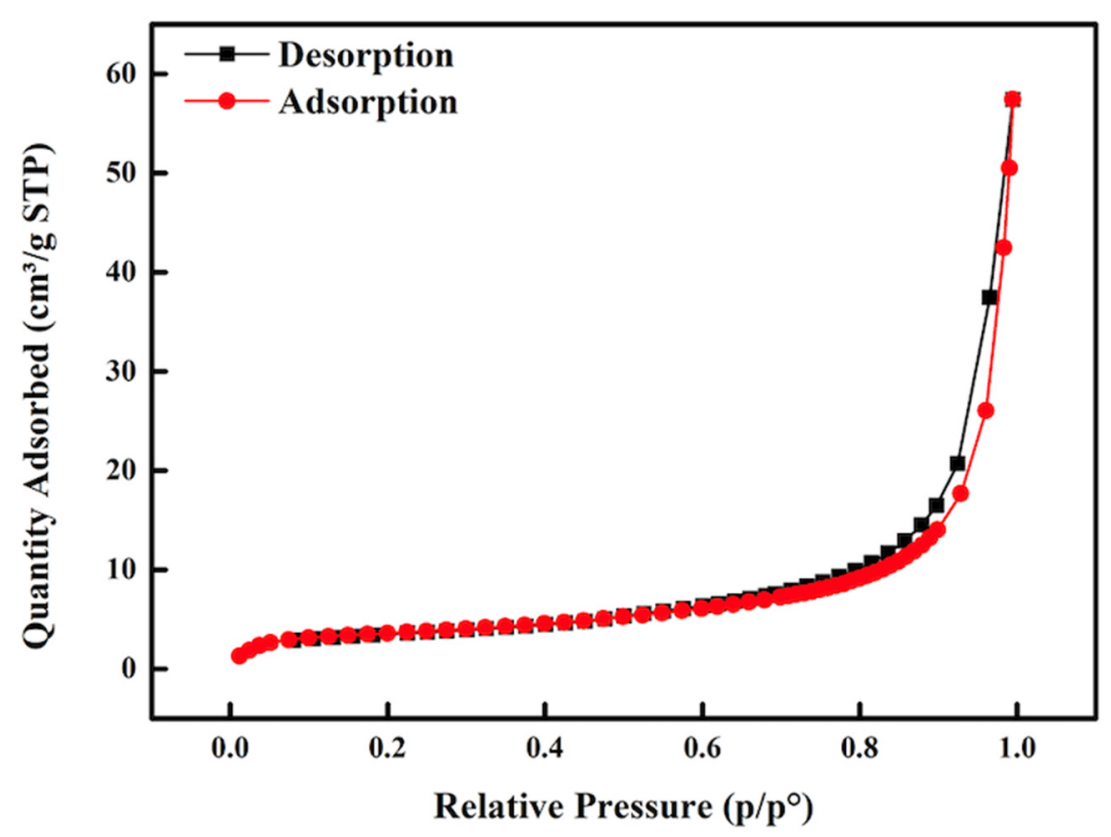

Figure 4. Nitrogen Adsorption-desorption isotherm of $\mathrm{CaO} / \mathrm{Al}_{2} \mathrm{O}_{3}$.

The calculated specific area, pore volume and pore diameter for pure $\mathrm{Al}_{2} \mathrm{O}_{3}$ and calcined $75 \% \mathrm{CaO}$ supported on $25 \% \mathrm{Al}_{2} \mathrm{O}_{3}$ are presented in Table 2 . Synthesised catalyst had a surface area of $13.0006 \mathrm{~m}^{2} / \mathrm{g}$ and $\mathrm{Al}_{2} \mathrm{O}_{3}$ had $0.6239 \mathrm{~m}^{2} / \mathrm{g}$, while pore volumes and diameters were $0.079732 \mathrm{~cm}^{3} / \mathrm{g}, 0.000857 \mathrm{~cm}^{3} / \mathrm{g}, 24.0371 \mathrm{~nm}$ and $5.9147 \mathrm{~nm}$ for prepared catalyst and alumina, respectively. An increase in surface area of $\mathrm{CaO} / \mathrm{Al}_{2} \mathrm{O}_{3}$ catalyst was observed after impregnating $75 \mathrm{wt} \%$ metal oxides onto alumina and thermal treatment. There was a significant increase in pore volume and pore size after the addition of $\mathrm{CaO}$, which contributed to the liquid-solid heterogeneous phase reaction and offered enough of a reaction surface area for the transformation of waste oil into biodiesel.

Recent studies showed that $\mathrm{CaO}$ calcined at low temperature $\left(500{ }^{\circ} \mathrm{C}\right)$ possesses a surface area of $5.2 \mathrm{~m}^{2} / \mathrm{g}$ and mean pore diameter of $11.9 \mathrm{~nm}$ [63], while the corresponding properties of the catalyst samples calcined at high temperatures $\left(700-950{ }^{\circ} \mathrm{C}\right)$ changed but not to a substantial extent $[61,63]$. It seems that the textural characteristics of $\mathrm{CaO}$ used in the experiment (from $\mathrm{CaO}-500{ }^{\circ} \mathrm{C}$ to $\mathrm{CaO}-900{ }^{\circ} \mathrm{C}$ ) are favorable for a liquidsolid heterogeneous phase reaction and provide a sufficient reaction surface area for the conversion of large triglyceride molecules. Significantly, the structural properties of $\mathrm{CaO}$ catalyst in the production of biodiesel effectively reduce greenhouse gas emissions. Nevertheless, in the study by Stankovic [64], the effect of calcination temperatures $\left(425^{\circ} \mathrm{C}\right.$, $450{ }^{\circ} \mathrm{C}, 475^{\circ} \mathrm{C}, 500^{\circ} \mathrm{C}$ ) on the yield of biodiesel was evaluated with an inference that $475^{\circ} \mathrm{C}$ gave the highest yield. After applying the same calcination temperature $\left(475^{\circ} \mathrm{C}\right)$, the pore diameter in this study increased to $24 \mathrm{~nm}$, which is superior by showing better permeability with an increased surface area. As seen in Table 2, this assisted in the transesterification of sunflower waste to biodiesel with a maximum yield of $98 \%$ using a lower catalyst weight and ratio (solid base: solid acid) compared to that used in achieving similar yields by Elias et al. [65]. Additionally, the yield found was a lot more than that reported by Marinkovic et al. when a high catalyst amount of $5.5 \mathrm{wt} \%$ was used prepared at high calcination of $700{ }^{\circ} \mathrm{C}[66]$. 


\subsection{GC Analysis}

The estimation of fatty acids content within each feedstock and the determination of fuel properties shown in Table 3 were determined by employing the GC. With double bonds being less stable than single bonds, their presence in the fatty acids affected the iodine number, viscosity, melting point, the efficiency of combustion and particulate matter formation related to soot [67], while improvement of average unsaturation helped with upgrading low-temperature performance but decreased the cetane number and caused poor oxidation stability [68]. Saturated fatty acids on other hand played a huge role in the cold flow properties relating to viscosity [69]. ASTM recommend viscosity of $1.9-6 \mathrm{~mm}^{2} / \mathrm{s}$ at $40{ }^{\circ} \mathrm{C}$ for biodiesel [70], and the high viscosity of vegetable oils prevents its direct usage in diesel engine [69] since this leads to the formation of deposits in the engine due to incomplete combustion [71]. As illustrated in Table 4, Waste palm oil (WPO) had a high viscosity of $47.5 \mathrm{cSt}$ followed by $37.1 \mathrm{cSt}$ for waste sunflower oil (WSO), which corresponds with their degree of saturated fatty acid, as seen in Table 3. The density of WSO and WPO in this study were found to be 0.9212 and $0.9168 \mathrm{~g} / \mathrm{cm}^{3}$, respectively. The flashpoints reported in this study were above the minimum requirement supported by the findings by [72-75]. It was observed that fresh oils had lower acid, nitrates, sulphates and glycol as compared to their respective waste oils; this is due to degradation and contaminations resulting from over usage through cooking and contact with other chemicals. This creates FFA and accelerates the oxidation process.

Table 3. Fatty Acids Compositions in waste cooking oils.

\begin{tabular}{cccc}
\hline FFA Acid Types & Carbon Chain & WPO (wt \%) & WSO (wt \%) \\
\hline Lauric & C12:0 & 0.42 & - \\
Myrisitc & C14:0 & 0.53 & - \\
Palmitic & C16:0 & 16.25 & 4.36 \\
Stearic & C18:0 & 1.50 & 3.39 \\
Oleic & C18:1 & 13.82 & 9.45 \\
Linoleic & C18:3 & 3.04 & 27.25 \\
\hline
\end{tabular}

FFA: Free Fatty Acids, WPO: Waste Palm Oil, WSO: Waste Sunflower Oil.

Table 4. Physico-chemical properties of waste oils and respective biodiesels produced.

\begin{tabular}{ccccccc}
\hline Properties & WPO & PB100 & WSO & SB100 & ASTM & EN\&SA \\
\hline Flash Point $\left({ }^{\circ} \mathrm{C}\right)$ & - & 170 & 200 & 175 & $>93$ & $>120$ \\
Oxidation Stability $(\mathrm{h})$ & - & 17.43 & - & 4.20 & $>3$ & $>6$ \\
Density at $15{ }^{\circ} \mathrm{C}\left(\mathrm{g} / \mathrm{cm}^{3}\right)$ & 0.9168 & 0.892 & 0.9212 & 0.8871 & 0.9 & $0.86-0.9$ \\
Viscosity at $40{ }^{\circ} \mathrm{C}(\mathrm{cSt})$ & 47.5 & 11.1 & 37.1 & 6 & $1.9-6$ & $3.5-5$ \\
Acid Value $(\mathrm{mg}$ of & 3.23 & 0.55 & 1.26 & 0.25 & $<0.5$ & $<0.5$ \\
KOH/g of oil) & 3 & 11 & 4 & 11 & - & - \\
Nitrates & 153 & 118 & 160 & 121 & - & - \\
Sulphates & 0 & 10 & 12 & 11 & - & - \\
Glycol & 11 & 11 & 11 & 12 & - & -
\end{tabular}

WPO: Waste Palm Oil, PB100: 100\% Palm biodiesel, WSO: Waste Sunflower Oil, SB100: 100\% Sunflower biodiesel, ASTM: American standard, EN: European standard, SA: South African Standard.

\subsection{Feedstocks and Biodiesel Quality Analysis}

Table 4 shows the properties of produced biodiesels of palm (PB100) and sunflower (SB100) from waste palm oil (WPO) and waste sunflower oil (WSO). According to the results of the biodiesels produced, most parameters met the specification set for use of biodiesel in diesel engines. These properties are crucial in fuel quality, performance, transportation and storage [76]. Notably, they depend on the feedstock used in the synthesis, which subsequently relates to the degree of saturation as seen in Table 3. Sunflower biodiesel is less flammable as indicated by a higher flashpoint of $175{ }^{\circ} \mathrm{C}$, while palm biodiesel had $170{ }^{\circ} \mathrm{C}$, which is preferred for handling and storage purposes [77]. This is because biodiesel and mineral diesel differ by $85 \%$ since the latter is usually above $150{ }^{\circ} \mathrm{C}$ [78]. 
In terms of the performance of palm, biodiesel was better since it had a high density, leading to a high mass of injected fuel causing more heat and creating more carbon, and therefore creating more power [79]. Additionally, oxidation stability in PB100 was superior, allowing for long-time stability at unfavourable conditions due to less polyunsaturated fatty acids in original feedstock [17], while for degradation during storage as indicated by acid number [72], sunflower biodiesel was the better fuel with a lower acid rate of $0.25 \mathrm{wt} \%$ which was below the standard limit and low compared to $0.55 \mathrm{wt} \%$ for palm biodiesel. Fuel atomisation was better in sunflower biodiesel, as indicated by reduced viscosity meeting standardisation [80]. Contaminants as indicated by the particulate matter of sulphates decreased in biodiesel from waste oils while nitrates increased as a result of more oxygen found in biodiesel [13,81]. Soot as well as glycol, which were higher in sunflower biodiesel, indicated more chances for incomplete combustion. Overall, sunflower biodiesel showed preferred fuel qualities; however, it also showed the possibility of lower oxidation stability under harsh conditions over longer storage time, as well as the possibility of incomplete combustion.

\subsection{Elemental Content Analysis}

\subsubsection{ICP-OES Analysis in Virgin, Waste Sunflower and Palm Oil and Their Biodiesels}

Table 5 represents the content of major and some minor elements found in virgin sunflower (VSO) oil, virgin palm oil (VPO), waste sunflower oil (WSO) and waste palm oil (WPO), as well as produced biodiesels. P, S and $\mathrm{Zn}$ are present in feedstocks since they are taken from the soil and are a result of fertilisers used during cultivation [82], while Ca, $\mathrm{K}$, $\mathrm{Mg}, \mathrm{Na}$ and $\mathrm{P}$ are usually introduced through the production process [83], and can lead to undesirable combustion if present at high concentrations. A report by Sánchez et al. [37] found that $\mathrm{Al}, \mathrm{Fe}, \mathrm{Mn}$ and $\mathrm{Zn}$ are minor elements that relate to the soil characteristics, which explains their presence in the virgin oils. There was an increase in phosphorus from $17.625 \mathrm{mg} / \mathrm{L}$ and $31.937 \mathrm{mg} / \mathrm{L}$ for virgin sunflower and palm oils to $21.264 \mathrm{mg} / \mathrm{L}$ and $44.455 \mathrm{mg} / \mathrm{L}$ for waste sunflower and palm oils, respectively. The absence of $\mathrm{Mg}$ and $\mathrm{K}$ in both sunflower and palm virgin oils was observed, while less than $0.068 \mathrm{mg} / \mathrm{L}$ of $\mathrm{Mg}$ and $0.012 \mathrm{mg} / \mathrm{L}$ of $\mathrm{K}$ was seen in WPO, though cooking using salts increased the waste produced [37]. A report by Avila Orozco et al. [83] showed that $\mathrm{Na}, \mathrm{K}, \mathrm{Ca}, \mathrm{S}$ and $\mathrm{P}$ came from raw material or chemical reagents. Lyra et al. [84] reported that their presence could have been incorporated due to the washing process with water. Therefore, since $\mathrm{CaO} / \mathrm{Al}_{2} \mathrm{O}_{3}$ was the catalyst used in synthesizing the biodiesels used in this study, a huge increase in Ca after production was seen from $0.025 \mathrm{mg} / \mathrm{L}$ and $0.345 \mathrm{mg} / \mathrm{L}$ to the drastic increment of $27.559 \mathrm{mg} / \mathrm{L}$ and $23.401 \mathrm{mg} / \mathrm{L}$ in biodiesel from waste sunflower and palm, which was associated with the sticking of injection or deposit on parts [85]. Sunflower methyl esters produced had lower elemental contaminates than palm methyl esters, which relate to better fuel quality but in terms of $\mathrm{Ca}, \mathrm{SB} 100$ was higher, which would increase the rate of oxidation [35]. According to standard requirements set by ASTM D6751 and EN 14214, Ca+Mg should be a maximum of $5 \mathrm{mg} / \mathrm{L}$ [86]. SB100 and PB100 failed this test which is of great concern since high levels of $\mathrm{Ca}$ and $\mathrm{Mg}$ form deposits [87], which accelerate oxidation reaction [40]. Nevertheless, elements of $\mathrm{Na}, \mathrm{Fe}, \mathrm{P}$ and $\mathrm{Al}$ were reduced after the conversion of waste feedstocks to biodiesel meeting specifications set. Operational problems caused by high levels of $\mathrm{Na}$ and $\mathrm{K}$ through corrosion [88], the positioning of catalytical converters and the ability of the after-treatment system were eliminated due to deterioration caused by high $\mathrm{P}$ in fuel $[89,90]$ and because sulphur is amongst the most concerning elements [40]. A high S content can affect the performance of engines [91], and the maximum limit set for sulphur in biodiesel is $10 \mathrm{mg} / \mathrm{L}$ [70,92]. It was observed that both biodiesels passed this test, which reduces corrosion in fuel containers [12]. 
Table 5. Elements content in virgin oils, waste oils and biodiesels produced.

\begin{tabular}{ccccccc}
\hline Elements $(\mathbf{m g} / \mathbf{L})$ & VSO & WSO & SB100 & VPO & WPO & PB100 \\
\hline $\mathrm{Na}$ & 0.971 & 1.133 & 0.333 & 1.648 & 2.399 & 0.383 \\
$\mathrm{Mg}$ & 0 & 0 & 0.125 & 0 & 0.068 & 0.266 \\
$\mathrm{~K}$ & 0 & 0 & 0 & 0 & 0.012 & 0 \\
$\mathrm{Ca}$ & 0.024 & 0.025 & 27.692 & 0.206 & 0.345 & 23.534 \\
$\mathrm{Fe}$ & 3.654 & 4.054 & 2.686 & 5.199 & 6.229 & 2.810 \\
$\mathrm{P}$ & 17.625 & 21.264 & 8.239 & 31.937 & 44.453 & 8.913 \\
$\mathrm{Al}$ & 1.682 & 1.969 & 0.870 & 2.861 & 4.109 & 0.921 \\
$\mathrm{Cu}$ & 0 & 0 & 0 & 0 & 0 & 0 \\
$\mathrm{Zn}$ & 1.185 & 1.216 & 1.623 & 1.407 & 1.601 & 1.666 \\
$\mathrm{~S}$ & - & - & 4 & - & - & 6 \\
\hline
\end{tabular}

VSO: Virgin Sunflower oil; WSO: Waste Sunflower Oil; VPO: Virgin Palm oil; WPO: Waste Palm Oil: SB100: 100\% Sunflower Biodiesel; PB100: 100\% Palm Biodiesel.

2.4.2. Effect of $\mathrm{Cu}, \mathrm{Fe}$ and $\mathrm{Zn}$ Metals on the Oxidation Stability of Biodiesels Produced from Waste Sunflower and Palm Oils

The main source of metals in vegetable oil is either its presence in raw material or contact with the manufacturing process and storage [40], as degradation and contamination happen due to undesirable compounds in the engine [31]. The presence of inorganic constituents in biodiesel can affect the quality of the fuel and cause the malfunctioning of engines [87], and since different materials are used for storage containers and engine parts, there is an issue with compatibility [93]. Corrosion in biodiesel is mainly due to the component nature and composition of biodiesel, as well as the environment [12,94]. Metallic storage tanks such as stainless steel and $\mathrm{Al}$ are normally used for storage [95], while in automobiles, the fuel is in direct contact with various parts of the engine like the fuel pump, fuel injector, pistons and piston rings, which are made of $\mathrm{Cu}, \mathrm{Al}$, brass$\mathrm{Br}$ (copper-rich alloy) and bronze [93]. Meanwhile, $\mathrm{Cu}$ has a huge effect on oxidizing biodiesel [96] and assessing $\mathrm{Cu}, \mathrm{Fe}$, and $\mathrm{Zn}$ is very crucial since along with $\mathrm{Ni}$, Sn and brass, they can affect stability through oxidation [97].

Figures 5 and 6 illustrates the degradation of metal contents in biodiesel with different fatty acids composition by the Rancimat method of EN 14112 specification with samples held at a temperature of $110^{\circ} \mathrm{C}$. It is clear that all metal contaminants had an influence in promoting oxidation in palm and sunflower biodiesel with a large effect within palm biodiesel, as these metals initiate the formation of free radicals [98]. As the concentration of metals increased, the oxidation stability decreased; however, after the concentration of 2 ppm, the induction period was not constant, as was previously reported by [99]. The results indicate that $\mathrm{Fe}$ greatly decreased the oxidation stability more than $\mathrm{Cu}$ or $\mathrm{Zn}$ in both biodiesels. This was strongly pronounced from $300 \mathrm{ppm}$ while $\mathrm{Cu}$ showed a significant influence at $100 \mathrm{ppm}$ onward in palm biodiesel. In sunflower biodiesel meanwhile, a gradual reduction was observed through to $700 \mathrm{ppm}$. Contrarily, the literature reported $\mathrm{Cu}$ to reduce oxidation stability more than Fe or Zn $[91,100,101]$ and the induction period became constant after 2 ppm $[99,102]$. Contrarily, this study had Fe as the most catalytic effect in reducing the induction period and it became constant after $500 \mathrm{ppm}$ of metal concentration for both biodiesels. Additionally, Palm biodiesel proved to have to degrade more and was found to have the most corrosiveness [12]. 


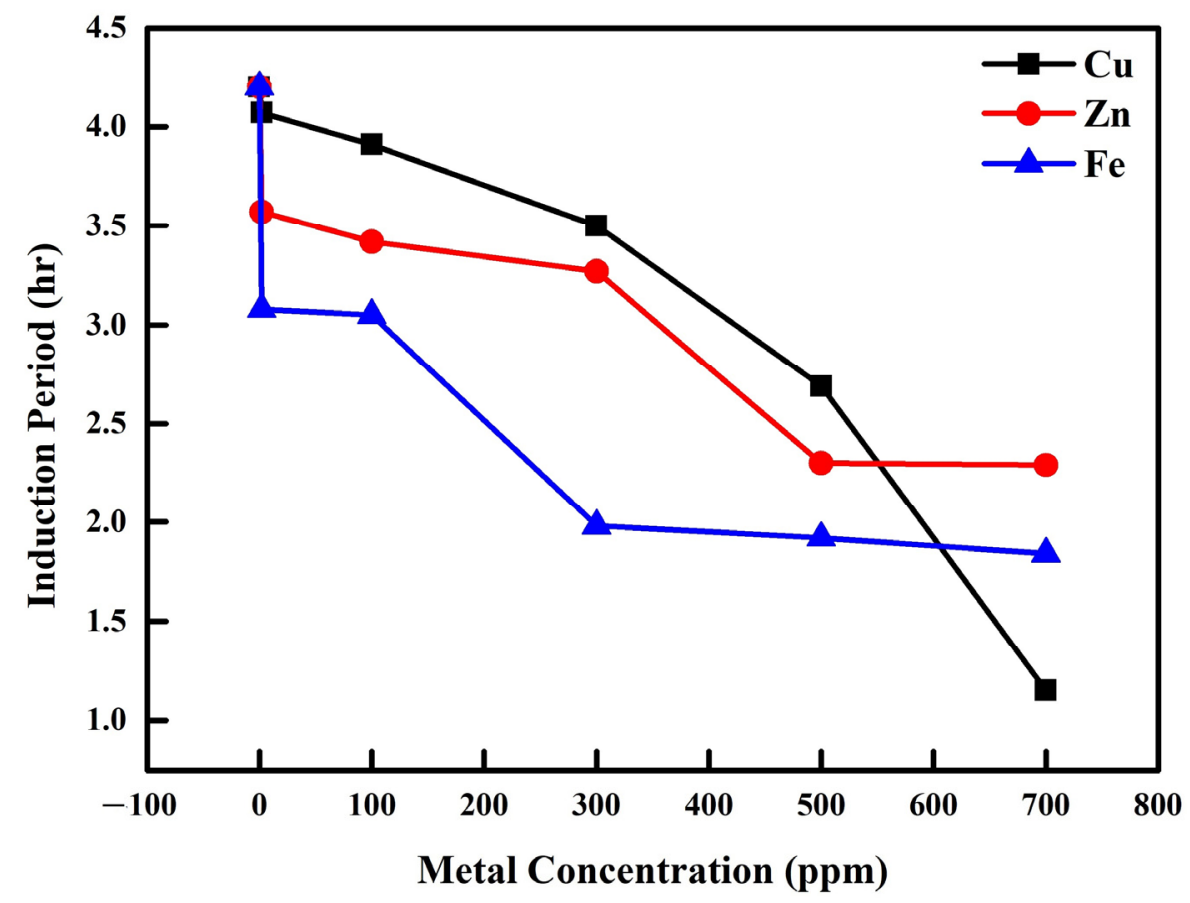

Figure 5. Oxidation stability in sunflower biodiesel before and after exposure to metals.

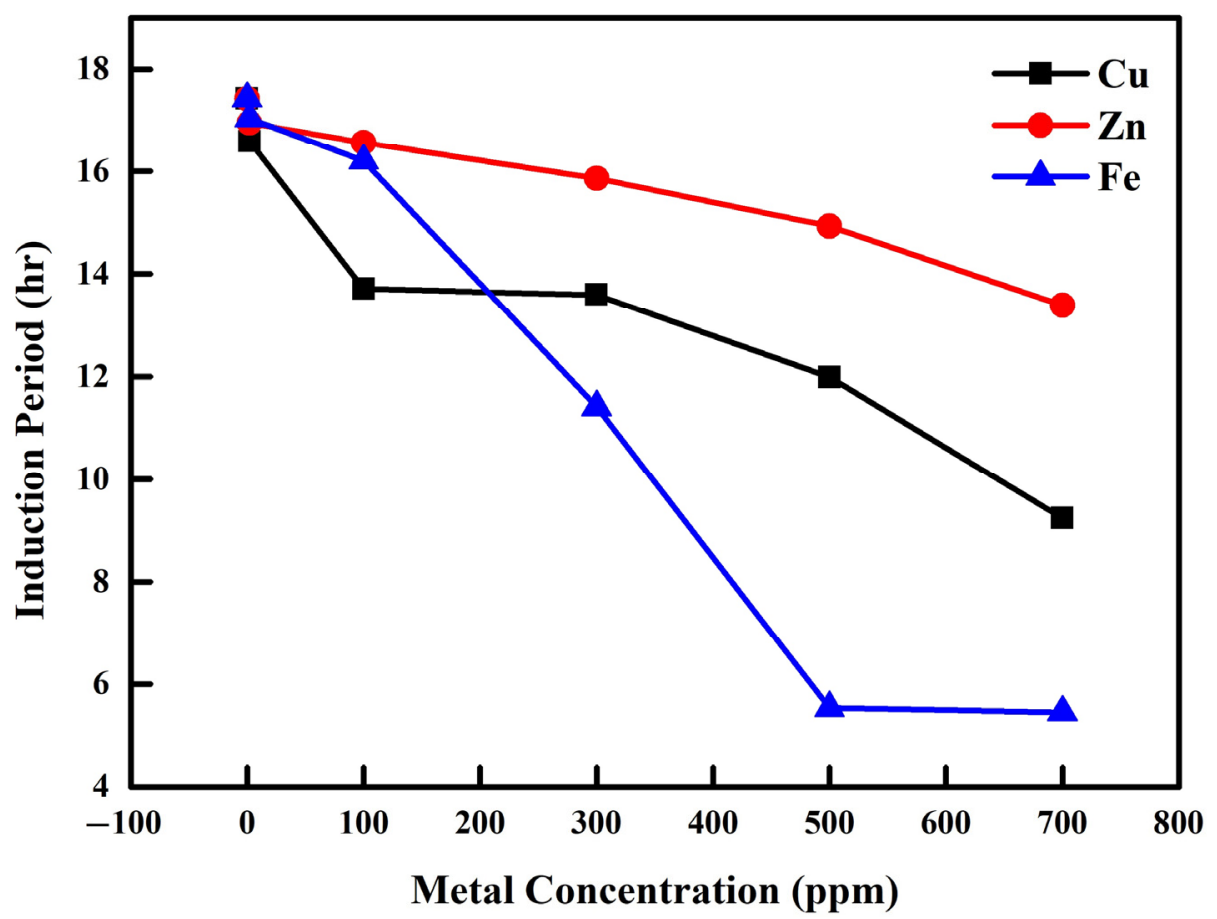

Figure 6. Oxidation stability in palm biodiesel before and after exposure to metals.

Sunflower biodiesel showed the highest corrosiveness impact of metals with Iron (Fe) followed by $\mathrm{Zn}$ and $\mathrm{Cu}$; however, at a concentration of $700 \mathrm{ppm}, \mathrm{Cu}$ was the most degraded metal. For PB100, the addition of metal concentrations lower than 100 ppm resulted in $\mathrm{Cu}$ having more corrosiveness followed by $\mathrm{Zn}$ and Fe but after 300 ppm, Fe was more corrosive than $\mathrm{Cu}$ and $\mathrm{Zn}$. This was supported by the studies of Baena and Calderón and Sentanuhady et al. [103,104], who found the metal that was most prone to corrosion in biodiesel is $\mathrm{Cu}$. Also, Shiotani and Goto [100] reported in their study that in PB100, Cu was found to have more degradation of oxidation followed by tin, iron, 
zinc and aluminium. Additionally, Thangavelu et al. [105] reported that copper had a higher corrosion rate than aluminium and stainless steel in that order. The investigation by Hu et al. [106] also reported that corrosion in biodiesel from rapeseed oil was in the order of stainless $\mathrm{Cu}>$ carbon steel $>\mathrm{Al}>$ stainless steel, while in the study by Fazal et al. [39], it was discovered that palm biodiesel degraded in the order of $\mathrm{Cu}>$ brass $(\mathrm{Br})>\mathrm{Al}>$ cast iron (CFe). Furthermore, in the experiment by Nurul et al. [107], where they investigated the corrosive behaviour of different steel materials which are mainly iron found in stainless steel, corrosion was localised while mild and galvanised steels were generalised.

\section{Materials and Methods}

\subsection{Chemical and Reagents}

Waste cooking oils of palm and sunflower were supplied by Suppa Oils (Cape Town, South Africa) and transesterification was conducted by the use of methanol (99.5\% SigmaAldrich, Johannesburg, South Africa) with the catalyst prepared using $\mathrm{CaO}$ ( $>68 \%$, SigmaAldrich, MO, USA) and $\mathrm{Al}_{2} \mathrm{O}_{3}$ (99.95\% Labchem, Johannesburg, South Africa). For elemental analysis by ICP, digestion was performed by utilising Nitric Acid (57.2\%), sulphuric acid (98.08\%) from KIMIX (Cape Town, South Africa) and Hydrogen Peroxide from 35\% Labchem (Johannesburg, South Africa). To evaluate the effect of added metal powders in biodiesel, Iron (>99,9\% Sigma-Aldrich, Johannesburg, South Africa), Zinc (98\% Merch, Gauteng, South Africa) and Cu (99,3\% AERONTEC, Cape Town, South Africa) were used.

\subsection{Preparation of Bifunctional Catalyst $\left(\mathrm{CaO} / \mathrm{Al}_{2} \mathrm{O}_{3}\right)$}

The bifunctional $\left(\mathrm{CaO} / \mathrm{Al}_{2} \mathrm{O}_{3}\right)$ catalyst was synthesised by preparing an aqueous solution made of $37.5 \mathrm{~g}$ primary reagent grade of calcium oxide and 12.5 Aluminium oxide support. The wet impregnation method was utilised [108]. However, a minor modification was done by using precursor salt of commercial $\mathrm{CaO}$, which was dissolved in distilled water. Thereafter, the introduction of alumina onto the precursor was carried out in a $100 \mathrm{~mL}$ flask. The mixture was vigorously stirred at room temperature for $4 \mathrm{~h}$ using an overhead stirrer (SCIENTECH Inc., Boulder, CO, USA) set at $600 \mathrm{rpm}$, as reported in the study by Zabeti et al. [109]. The mixture was filtered under vacuum with grade 1 Whatman filter paper (Merch, Darmstadt, Germany). Thereafter, drying was accomplished in a static oven (Scientific, Kyalami, South Africa) set to $120^{\circ} \mathrm{C}$ for $18 \mathrm{~h}$. Prior to activation, the dried paste was crushed into fine powders by the use of pestle and mortar. To calcine the catalyst, a muffle furnace which was set at $475^{\circ} \mathrm{C}$, was used for $5 \mathrm{~h}$. with a ramping rate of $5^{\circ} \mathrm{C} / \mathrm{min}[64,108]$. After calcination, the catalyst was left to cool down at room temperature and was then transferred to a closed glass vial for storage.

\subsection{Transesterification}

In this study, the $75 \% \mathrm{CaO} / 25 \% \mathrm{Al}_{2} \mathrm{O}_{3}$ catalyst was used to investigate the effect of conversion rate per catalyst (rate of yield) through a transesterification reaction and its contribution towards the elemental content within biodiesel. The reaction was carried out in a $250 \mathrm{~mL}$ round glass flask connected to a condenser, which avoided evaporation by having inlet and outlet systems to cool down the temperature. Waste cooking oil was added into the round glass flask with a thermometer placed inside it. The oil was pre-heated to $40{ }^{\circ} \mathrm{C}$ and the flask was slowly introduced into a water bath on a hotplate. A total of $100 \mathrm{~g}$ of methanol to oil ratio was mixed with $2.5 \mathrm{wt} \%$ of catalyst synthesised and poured into a $250 \mathrm{~mL}$ round-flask which had a stirrer; the mixture was then stirred vigorously. The hotplate was roughly set at $110^{\circ} \mathrm{C}$ and as the temperature reading on the thermometer increased to $60^{\circ} \mathrm{C}$, the reaction was kick-started. The inlet and outlet flow of water that was connected to the condenser assisted in maintaining a constant temperature throughout the reaction and the mixing speed was set at $1300 \mathrm{rpm}$. After the reaction was completed, the products were poured into centrifuge tubes with equal masses and were centrifuged at $2200 \mathrm{rpm}$ using Ohaus Multi Centrifuge for $10 \mathrm{~min}$. Thereafter, samples were poured into separatory funnels for the separation of biodiesel and glycerol into phases, while solids 
were left in the centrifuge tubes. Distilled water used in the biodiesel washing was heated to a temperature of $50{ }^{\circ} \mathrm{C}$. During the washing stage, three times the amount of water to biodiesel was used. This allowed for clean biodiesel, as the washed water was clear. The biodiesel was thereafter placed on a hotplate in a beaker and a small amount of $\mathrm{Na}_{2} \mathrm{SO}_{4}$ was used to dry any trace amount of water that might have been left in the biodiesel. The product was then left to cool and stored for analysis.

\subsection{Characterisation Techniques}

The Infrared spectral was performed using a spectrum high performance TWO LITA FTIR instrument (PerkinElmer, Inc., Walthan, MA, USA) equipped with a lithium tantalate detector $\left(\mathrm{LiTaO}_{3}\right)$ and Spectrum $10^{\mathrm{TM}}$ software. All spectra were collected at a range of 400 to $4000 \mathrm{~cm}^{-1}$ with a resolution of $4 \mathrm{~cm}^{-1}$ using an average of 10 scans.

The morphology of the catalyst was assessed using a Field-Emission Scanning Electron Microscope (The Nova NanoSEM 230, Hillsboro, OR, USA) equipped with an in-lens secondary electron and backscattered electron detectors. The element was operated at an accelerating voltage of $5 \mathrm{kV}$ using TESCAN MIRA.

The crystalline phases present were identified using a multipurpose X-ray diffractometer (XRD), D8-Advance (BRUKER AXS, Karlsruhe, Germany), which was operating in a continuous scan in locked coupled-mode using $\mathrm{Cu}-\mathrm{K} \alpha$ radiation with a wavelength $(\lambda)$ of $1.5406 \AA$ at $40 \mathrm{kV}$ and $40 \mathrm{~mA}$. The measurements were run within a range in $2 \theta\left(0.5^{\circ}\right.$ to $\left.80^{\circ}\right)$ with a typical step size of $0.034^{\circ}$. A position-sensitive detector, Lyn-Eye, was used to record diffraction data at a screening speed of $0.5 \mathrm{~s} / \mathrm{step}$, which is equivalent to an effective time of $92 \mathrm{~s} /$ step for a scintillation counter. The XRD phases were identified using an Internal Center for Diffraction Data (ICDD) PDF database 1999 using EVA software from BRUKER.

The Brunauer-Emmett-Teller (BET) was employed to determine the surface area, pore volume and pore size distribution of the synthesised catalysts using TriStar II 3020 Analyser version 2.00 (Micromeritics, Instruments Corporation, GA, USA) at a liquid nitrogen and operation bath temperature of $77.350 \mathrm{~K}$. The BJH method was used for calculating pore volume distribution and average pore diameter while for the surface area, BET analysis was used. The sample was degassed overnight at $200{ }^{\circ} \mathrm{C}$, while the reference $\mathrm{Al}_{2} \mathrm{O}_{3}$ was degassed at $300{ }^{\circ} \mathrm{C}$ for $3 \mathrm{~h}$ to obtain reasonable adsorption-desorption isotherms.

The fatty acids concentration was obtained using GC 7890A (Agilent Technologies, Inc, Waldbronn, Germany) detailing components within feedstocks, as materials were separated from each other by the number of their constituent atoms. This follows ASTM 6584 and EN 14214 standardisation.

Physico-chemical properties of feedstock and biodiesel were analysed for properties such as acid number, density, viscosity, oxidation stability, flash point and total contamination using conventional methods according to ASTM and EN methods.

\section{Conclusions}

A highly active bifunctional catalyst of $\mathrm{CaO} / \mathrm{Al}_{2} \mathrm{O}_{3}$ was prepared by the wet impregnation method and used for its transesterification reaction. The catalyst was found to be suitable for the conversion of oils with a high FFA such as waste cooking oils ( $>15 \%$ FFA) to FAME; however, it influenced the increase of concentration of Ca within biodiesel. Biodiesel properties were evaluated according to ASTM and EN methods. The quality was highly influenced by the molecular structure, the chain length and the degree of saturation in the feedstock used for biodiesel production. From the results obtained, it was determined that biodiesels produced from waste palm oil had longer oxidation stability than those produced from waste sunflower oil. Additionally, with the evaluation of the oxidation stability through the addition of $\mathrm{Fe}, \mathrm{Cu}$ and $\mathrm{Zn}$ metal powders to biodiesels concentrations of 2-700 ppm, the findings showed that all metals had an impact on reducing the induction time for concentrations of 2-700 ppm. The intensification in oxidation stability was influenced by the increase in metal concentrations and the type of biodiesel produced. In both biodiesels, Fe decreased oxidation stability and significantly failed EN 
specifications in PB100 from 500-700 ppm and in all concentrations of SB100. Furthermore, a remarkable decrease of $\mathrm{Cu}$ in SB100 at a concentration of $700 \mathrm{ppm}$ was also observed and the order of overall corrosiveness of metals in sunflower biodiesel was $\mathrm{Fe}>\mathrm{Zn}>\mathrm{Cu}$ and the equivalent in palm biodiesel was $\mathrm{Fe}>\mathrm{Cu}>\mathrm{Zn}$, with most metals impacting on induction time reductions.

Author Contributions: Conceptualisation, I.S., U.O.A., O.O. and O.A.O.; methodology, I.S.; software, I.S.; validation, U.O.A. and O.A.O.; formal analysis, I.S.; investigation, U.O.A., O.O., O.A.O.; resources, I.S.; data curation, U.O.A. and O.A.O.; writing-original draft preparation, I.S.; writingreview and editing, I.S., U.O.A., O.A.O.; visualisation, I.S., U.O.A. and O.A.O.; supervision, U.O.A., O.O. and O.A.O.; project administration, O.A.O. and O.O.; funding acquisition, O.A.O. and O.O. All authors have read and agreed to the published version of the manuscript.

Funding: This research was funded by the Cape Peninsula University of Technology. The Article Processing Charges (APC) were funded by the Cape Peninsula University of Technology.

Data Availability Statement: Not Applicable.

Acknowledgments: The authors would like to thank the Cape Peninsula University of Technology Research Fund for the financial support received, as well as the use of these laboratories: Chemical Engineering Department (oil and gas lab) for biodiesel synthesis, Food Science and Technology Department Rancimat and GC labs for waste oils and biodiesel analysis, Chemistry Department ICP lab for elemental analysis, University of Cape Town (UCT) and iThemba labs for catalyst characterisation and Oilwatch laboratories for biodiesel characterisation.

Conflicts of Interest: The authors declare no conflict of interest.

\section{References}

1. Green, O.; Studies, G. OECD Green Growth Studies. Director 2012, 9-104. [CrossRef]

2. Organization of Petroleum Exporting Countries (OPEC). World Oil Outlook 2040; OPEC: Vienna, Austria, 2017; pp. 61-161. ISBN 978-3-9503936-4-4. [CrossRef]

3. Magsi, H. Industrialization, Environment and Pollution. Dipl. Insight 2015, 7, 24-26. Available online: https://www.researchgate. net/publication/270899735_Industrialization_Environment_and_Pollution (accessed on 2 August 2021).

4. Muhammad, M.B.; Aziz, R.A.; Yew, V.W.C. Socio-Economic Effects of Industrialization in the Society. Int. J. Environ. Ecol. Fam. Urban. Stud. 2018, 8, 24-29. Available online: https://www.researchgate.net/publication/327966349_Socio_-_Economic_Effects_ of_Industrialization_in_the_Society/citations (accessed on 2 August 2021).

5. Baskar, G.; Aiswarya, R. Trends in catalytic production of biodiesel from various feedstocks. Renew. Sustain. Energy Rev. 2016, 57, 496-504. [CrossRef]

6. Jabade, S.; Sakthivel, M.; Chavan, S. Bio-diesel as an alternative fuel for compression ignition engine: A review. Int. J. Adv. Sci. Technol. 2020, 29, 18-28. [CrossRef]

7. Torres-García, M.; García-Martín, J.F.; Jiménez-Espadafor Aguilar, F.J.; Barbin, D.F.; Álvarez-Mateos, P. Vegetable oils as renewable fuels for power plants based on low and medium speed diesel engines. J. Energy Inst. 2019, 93, 953-961. [CrossRef]

8. Atabani, A.E.; Silitonga, A.S.; Badruddin, I.A.; Mahlia, T.M.I.; Masjuki, H.H.; Mekhilef, S. A comprehensive review on biodiesel as an alternative energy resource and its characteristics. Renew. Sustain. Energy Rev. 2012, 16, 2070-2093. [CrossRef]

9. Alhindawi, R.; Nahleh, Y.A.; Kumar, A.; Shiwakoti, N. Projection of greenhouse gas emissions for the road transport sector based on multivariate regression and the double exponential smoothing model. Sustainability 2020, 12, 9152. [CrossRef]

10. Abbaszaadeh, A.; Ghobadian, B.; Omidkhah, M.R.; Najafi, G. Current biodiesel production technologies: A comparative review. Energy Convers. Manag. 2012, 63, 138-148. [CrossRef]

11. Harfoot, M.B.J.; Tittensor, D.P.; Knight, S.; Arnell, A.P.; Blyth, S.; Brooks, S.; Butchart, S.H.M.; Hutton, J.; Jones, M.I.; Kapos, V.; et al. Present and future biodiversity risks from fossil fuel exploitation. Conserv. Lett. 2018, 11, 1-13. [CrossRef]

12. Nguyen, X.P.; Vu, H.N. Corrosion of the metal parts of diesel engines in biodiesel-based fuels. Int. J. Renew. Energy Dev. 2019, 8, 119-132. [CrossRef]

13. Nair, J.N. Study of Biodiesel Blends and Emission Characteristics of Study of Biodiesel Blends and Emission Characteristics of Biodiesel. (ISO 3297: 2007). Int. J. Innov. Rev. Sci. Eng. Technol. 2013, 2, 3710-3715. Available online: https://www.researchgate. net/publication/281430011_STUDY_OF_BIODIESEL_BLENDS_AND_EMISSION_CHARACTERISTICS_OF_BIODIESEL (accessed on 2 August 2021).

14. Borugadda, V.B.; Paul, A.K.; Chaudhari, A.J.; Kulkarni, V.; Sahoo, N.; Goud, V.V. Influence of Waste Cooking Oil Methyl Ester Biodiesel Blends on the Performance and Emissions of a Diesel Engine. Waste Biomass Valorization 2018, 9, 283-292. [CrossRef]

15. Peng, D.X. Effect of unleaded gasoline blended with biofuels on gasoline injector wear and exhaust emissions. Ind. Lubr. Tribol. 2017, 69, 208-214. [CrossRef] 
16. Carraretto, C.; Macor, A.; Mirandola, A.; Stoppato, A.; Tonon, S. Biodiesel as alternative fuel: Experimental analysis and energetic evaluations. Energy 2004, 29, 2195-2211. [CrossRef]

17. Moser, B.R.; Bryan, R. Moser: Biodiesel production, properties, and feedstocks. Vitr. Cell. Dev. Biol. Plant. 2009, 45, 229-266. [CrossRef]

18. Mandolesi de Araújo, C.D.; de Andrade, C.C.; de Souza, E.; Silva, E.; Dupas, F.A. Biodiesel production from used cooking oil: A review. Renew. Sustain. Energy Rev. 2013, 27, 445-452. [CrossRef]

19. Rocha, L.D.S.; Corrêa, S.M. Determination of size-segregated elements in diesel-biodiesel blend exhaust emissions. Environ. Sci. Pollut. Res. 2018, 25, 18121-18129. [CrossRef] [PubMed]

20. Zhang, Y.; Dubé, M.A.; McLean, D.D.; Kates, M. Biodiesel production from waste cooking oil: 2. Economic assessment and sensitivity analysis. Bioresour. Technol. 2003, 90, 229-240. [CrossRef]

21. Kulkarni, M.G.; Dalai, A.K. Waste cooking oil-An economical source for biodiesel: A review. Ind. Eng. Chem. Res. 2006, 45, 2901-2913. [CrossRef]

22. Boadu, K.O.; Joel, O.F.; Essumang, D.K.; Evbuomwan, B.O. A Review of Methods for Removal of Contaminants in Used Lubricating Oil. Chem. Sci. Int. J. 2019, 26, 1-11. [CrossRef]

23. Julianto, T.S.; Nurlestari, R. Waste cooking oil as source for renewable fuel in Romania Waste cooking oil as source for renewable fuel in Romania. In Proceedings of the 7th International Conference on Advanced Concept in Mechanical Engineering, Iasi, Romania, 9-10 June 2016; Volume 146, pp. 1-6. [CrossRef]

24. Agarwal, M.; Chauhan, G.; Chaurasia, S.P.; Singh, K. Journal of the Taiwan Institute of Chemical Engineers Study of catalytic behavior of $\mathrm{KOH}$ as homogeneous and heterogeneous catalyst for biodiesel production. J. Taiwan Inst. Chem. Eng. 2012, 43, 89-94. [CrossRef]

25. Zhu, H.; Wu, Z.; Chen, Y.; Zhang, P.; Duan, S.; Liu, X.; Mao, Z. Preparation of biodiesel catalyzed by solid super base of calcium oxide and its refining process. Chin. J. Catal. 2006, 27, 391-396. [CrossRef]

26. Calero, J.; Luna, D.; Sancho, E.D.; Luna, C.; Bautista, F.M.; Romero, A.A.; Posadillo, A.; Verdugo, C. Development of a new biodiesel that integrates glycerol, by using $\mathrm{CaO}$ as heterogeneous catalyst, in the partial methanolysis of sunflower oil. Fuel 2014, 122, 94-102. [CrossRef]

27. Alba-Rubio, A.C.; Santamaría-González, J.; Mérida-Robles, J.M.; Moreno-Tost, R.; Martín-Alonso, D.; Jiménez-López, A.; MairelesTorres, P. Heterogeneous transesterification processes by using $\mathrm{CaO}$ supported on zinc oxide as basic catalysts. Catal. Today 2010, 149, 281-287. [CrossRef]

28. Wen, D.; Jiang, H.; Zhang, K. Supercritical fluids technology for clean biofuel production. Prog. Nat. Sci. 2009, 19, $273-284$. [CrossRef]

29. Banerjee, M.; Dey, B.; Talukdar, J.; Chandra, M. Production of biodiesel from sun fl ower oil using highly catalytic bimetallic gold e silver core e shell nanoparticle. Energy 2014, 69, 695-699. [CrossRef]

30. Changmai, B.; Vanlalveni, C.; Ingle, A.P.; Bhagat, R.; Rokhum, L. Widely used catalysts in biodiesel production: A review. RSC Adv. 2020, 10, 41625-41679. [CrossRef]

31. Nogueira, T.; Lucio, C. Determination of $\mathrm{Ca}, \mathrm{K}, \mathrm{Mg}, \mathrm{Na}$, sulfate, phosphate, formate, acetate, propionate, and glycerol in biodiesel by capillary electrophoresis with capacitively coupled contactless conductivity detection. Microchem. J. 2011, 99, 267-272. [CrossRef]

32. Elkadi, M.; Pillay, A.; Manuel, J.; Khan, M.Z.; Stephen, S.; Molki, A. Sustainability study on heavy metal uptake in neem biodiesel using selective catalytic preparation and hyphenated mass spectrometry. Sustainability 2014, 6, 2413-2423. [CrossRef]

33. Isis, A.; de Oliveira, A.P.; de Magalhães, M.R.L.; Villa, R.D. Determination of sodium and potassium in biodiesel by flame atomic emission spectrometry, with dissolution in ethanol as a single sample preparation step. Fuel 2012, 93, 381-384. [CrossRef]

34. Chaves, E.S.; de Loos-vollebregt, M.T.C.; Curtius, A.J.; Vanhaecke, F. Spectrochimica Acta Part B Determination of trace elements in biodiesel and vegetable oil by inductively coupled plasma optical emission spectrometry following alcohol dilution. Spectrochim. Acta Part B At. Spectrosc. 2011, 66, 733-739. [CrossRef]

35. Mendil, D.; Uluözlü, Ö.D.; Tüzen, M.; Soylak, M. Investigation of the levels of some element in edible oil samples produced in Turkey by atomic absorption spectrometry. J. Hazard. Mater. 2009, 165, 724-728. [CrossRef]

36. Pillay, A.E.; Elkadi, M.; Fok, S.C.; Stephen, S.; Manuel, J.; Khan, M.Z.; Unnithan, S. A comparison of trace metal profiles of neem biodiesel and commercial biofuels using high performance ICP-MS. Fuel 2012, 97, 385-389. [CrossRef]

37. Sánchez, R.; Sánchez, C.; Lienemann, C.P.; Todolí, J.L. Metal and metalloid determination in biodiesel and bioethanol. J. Anal. At. Spectrom. 2015, 30, 64-101. [CrossRef]

38. Waynick, J.A. Characterization of biodiesel oxidation and oxidation products. Tech. Lit. Rev. 2005, 1-51. [CrossRef]

39. Fazal, M.A.; Haseeb, A.S.M.A.; Masjuki, H.H. Degradation of automotive materials in palm biodiesel. Energy 2012, 40, 76-83. [CrossRef]

40. Garrido, M.D.; Frías, I.; Díaz, C.; Hardisson, A. Concentrations of metals in vegetable edible oils. Food Chem. 1994, 50, 237-243. [CrossRef]

41. Santos, D.C.M.B.; Guida, M.A.B.; Barbosa, I.S.; Passos, M.L.C. Evaluation of Digestion Procedures for Simultaneous Determination of $\mathrm{Ca}, \mathrm{P}, \mathrm{Mg}, \mathrm{K}$ and $\mathrm{Na}$ in Biodiesel by Inductively Coupled Plasma Optical Emission Spectrometry. J. Braz. Chem. Soc. 2010, 21, 2278-2284. [CrossRef] 
42. Health Effects Institute: Understanding the Health Effects of Components of the Particulate Matter Mix: Progress and Next Steps. HEI Perspect. 2002, 1-20. Available online: https://www.healtheffects.org/publication/understanding-health-effectscomponents-particulate-matter-mix-progress-and-next-steps (accessed on 2 August 2021).

43. Ruzinska, E.; Stollmann, V.; Hagara, V.; Jablonski, M. Analysis of selected heavy metals in biomass for preparation of biofuelsPart II. Determination of heavy metals content. Ann. Wars. Univ. Life Sci. SGGW. For. Wood Technol. 2015, 92, $383-389$.

44. Black, L.T. Comparison of three atomic absorption techniques for determining metals in soybean oil. J. Am. Oil Chem. Soc. 1975, 52, 88-91. [CrossRef]

45. Sompech, S.; Dasri, T.; Thaomola, S. Preparation and characterization of amorphous silica and calcium oxide from agricultural wastes. Orient. J. Chem. 2016, 32, 1923-1928. [CrossRef]

46. Aitlaalim, A.; Ouanji, F.; Benzaouak, A.; El Mahi, M.; Lotfi, E.M.; Kacimi, M.; Liotta, L.F. Utilization of waste grooved razor shell (Grs) as a catalyst in biodiesel production from refined and waste cooking oils. Catalysts 2020, 10, 703. [CrossRef]

47. Hosseini, S.A.; Niaei, A.; Salari, D. Production of $\gamma-\mathrm{Al}_{2} \mathrm{O}_{3}$ from Kaolin. Open J. Phys. Chem. 2011, 1, 23-27. [CrossRef]

48. Kesserwan, F.; Ahmad, M.N.; Khalil, M.; El-Rassy, H. Hybrid CaO/ $\mathrm{Al}_{2} \mathrm{O}_{3}$ aerogel as heterogeneous catalyst for biodiesel production. Chem. Eng. J. 2020, 385, 2-11. [CrossRef]

49. Ruan, G.; Zhang, Z.; Yin, M.; Xu, G. Effect of aluminum powder on the synthesis of corundum-mullite composites. Ceram. Silikaty. 2013, 57, 133-137.

50. Granados-Correa, F.; Bonifacio-Martínez, J.; Hernández-Mendoza, H.; Bulbulian, S. Capture of $\mathrm{CO}_{2}$ on $\gamma-\mathrm{Al}_{2} \mathrm{O}_{3}$ materials prepared by solution-combustion and ball-milling processes. J. Air Waste Manag. Assoc. 2016, 66, 643-654. [CrossRef]

51. Mirghiasi, Z.; Bakhtiari, F.; Darezereshki, E.; Esmaeilzadeh, E. Preparation and characterization of CaO nanoparticles from $\mathrm{Ca}(\mathrm{OH})_{2}$ by direct thermal decomposition method. J. Ind. Eng. Chem. 2014, 20, 113-117. [CrossRef]

52. Yang, W.; Feng, Y.; Chu, W. Promotion Effect of $\mathrm{CaO}$ Modification on Mesoporous $\mathrm{Al}_{2} \mathrm{O}_{3}-\mathrm{Supported} \mathrm{Ni}^{\mathrm{Catalyst}}$ for $\mathrm{CO}_{2}$ Methanation. Int. J. Chem. Eng. 2016, 2016, 2041821. [CrossRef]

53. Intarasiri, S.; Ratana, T.; Sornachamni, T.; Tungkamani, S.; Phongaksorn, M. Pore size effect of mesoporous support on metal particle size of $\mathrm{Co} / \mathrm{SiO}_{2}$ catalyst in Fischer-Tropsch synthesis. Int. J. Adv. Appl. Sci. 2018, 5, 80-85. [CrossRef]

54. Imtiaz, A.; Farrukh, M.A.; Khaleeq-Ur-Rahman, M.; Adnan, R. Micelle-assisted synthesis of Almiddot; CaO nanocatalyst: Optical properties and their applications in photodegradation of 2,4,6-trinitrophenol. Sci. World J. 2013, 2013, 641420. [CrossRef]

55. Teo, S.H.; Taufiq-Yap, Y.H.; Rashid, U.; Islam, A. Hydrothermal effect on synthesis, characterization and catalytic properties of calcium methoxide for biodiesel production from crude Jatropha curcas. RSC Adv. 2015, 5, 4266-4276. [CrossRef]

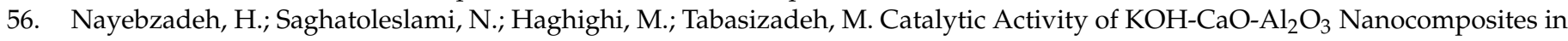
Biodiesel Production: Impact of Preparation Method. Int. J. Self Propagating High Temp. Synth. 2019, 28, 18-27. [CrossRef]

57. Marinković, D.M.; Avramović, J.M.; Stanković, M.V.; Stamenković, O.S.; Jovanović, D.M.; Veljković, V.B. Synthesis and characterization of spherically-shaped $\mathrm{CaO} / \Gamma-\mathrm{Al}_{2} \mathrm{O}_{3}$ catalyst and its application in biodiesel production. Energy Convers. Manag. 2017, 144, 399-413. [CrossRef]

58. Wacharasindhu, S.; Likitmaskul, S.; Punnakanta, L.; Chaichanwatanakul, K.; Angsusingha, K.; Tuchinda, C. Serum IGF-I and IGFBP-3 Levels for Normal Thai Children and their Usefulness in Clinical Practice. J. Med. Assoc. Thail. 1998, 81, 420-430.

59. Yang, F.; Ning, Z.; Liu, H. Fractal characteristics of shales from a shale gas reservoir in the Sichuan Basin, China. Fuel 2014, 115, 378-384. [CrossRef]

60. Xu, L.; Zhang, J.; Ding, J.; Liu, T.; Shi, G.; Li, X.; Dang, W.; Cheng, Y.; Guo, R. Pore structure and fractal characteristics of different shale lithofacies in the dalong formation in the western area of the lower yangtze platform. Minerals 2020, 10, 72. [CrossRef]

61. Zhu, L.; Cao, M.; Zhou, H.; Zhang, N.; Zheng, J.; Li, Y.; Chen, B.H. A highly stable and active CaO/ $\mathrm{Al}_{2} \mathrm{O}_{3}$ base catalyst in the form of calcium aluminate phase for oxidation of cyclohexanone to $\varepsilon$-caprolactone. Catal. Lett. 2014, 144, 1188-1196. [CrossRef]

62. Huang, B.; Bartholomew, C.H.; Woodfield, B.F. Improved calculations of pore size distribution for relatively large, irregular slit-shaped mesopore structure. Microporous Mesoporous Mater. 2014, 184, 112-121. [CrossRef]

63. Ljupković, R.B.; Radulović, N.S.; Bojić, A.L.; Zarubica, A.R.; Mićić, R.D.; Tomić, M.D. Značaj strukturnih karakteristika CaO katalizatora za proizvodnju biodizela: Uticaj na smanjenje emisije gasova staklene bašte. Hem. Ind. 2014, 68, 399-412. [CrossRef]

64. Stankovic, M. Preparation of $\mathrm{CaO} / \gamma-\mathrm{Al}_{2} \mathrm{O}_{3}$ catalyst for biodiesel fuels. The catalytic activity in relation to thermal. In Proceedings of the 12th International Conference on Fundamental and Applied Aspects of Physical Chemistry, Belgrade, Serbia, 22-26 September 2014; pp. 2-3. [CrossRef]

65. Elias, S.; Rabiu, A.M.; Okeleye, B.I.; Okudoh, V.; Oyekola, O. Bifunctional heterogeneous catalyst for biodiesel production from waste vegetable oil. Appl. Sci. 2020, 10, 3153. [CrossRef]

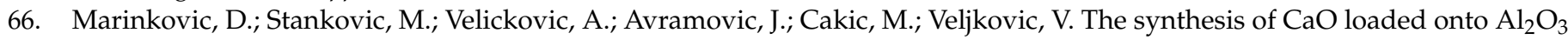
from calcium acetate and its application in transesterification of the sunflower oil. Savrem. Tehnol. 2015, 4, 26-32. [CrossRef]

67. Capuano, D.; Costa, M.; Di Fraia, S.; Massarotti, N.; Vanoli, L. Direct use of waste vegetable oil in internal combustion engines. Renew. Sustain. Energy Rev. 2017, 69, 759-770. [CrossRef]

68. Mahmudul, H.M.; Hagos, F.Y.; Mamat, R.; Adam, A.A.; Ishak, W.F.W.; Alenezi, R. Production, characterization and performance of biodiesel as an alternative fuel in diesel engines-A review. Renew. Sustain. Energy Rev. 2017, 72, 497-509. [CrossRef]

69. Chhetri, A.; Watts, K.; Islam, M. Waste Cooking Oil as an Alternate Feedstock for Biodiesel Production. Energies 2008, 1, 3. [CrossRef]

70. Knothe, G. Analyzing biodiesel: Standards and other methods. JAOCS J. Am. Oil Chem. Soc. 2006, 83, 823-833. [CrossRef] 
71. Axelsson, L.; Franzén, M.; Ostwald, M.; Berndes, G.; Lakshmi, G.; Ravindranath, N.H. Perspective: Jatropha cultivation in southern India: Assessing farmers' experiences. Biofuels Bioprod. Biorefin. 2012, 6, 246-256. [CrossRef]

72. Yasin, M.H.M.; Mamat, R.; Yusop, A.F.; Rahim, R.; Aziz, A.; Shah, L.A. Fuel physical characteristics of biodiesel blend fuels with alcohol as additives. Procedia Eng. 2013, 53, 701-706. [CrossRef]

73. Bukkarapu, K.R.; Rahul, T.S.; Kundla, S.; Vardhan, G.V. Effects of blending on the properties of diesel and palm biodiesel. IOP Conf. Ser. Mater. Sci. Eng. 2018, 330, 012092. [CrossRef]

74. Giakoumis, E.G. Analysis of 22 vegetable oils' physico-chemical properties and fatty acid composition on a statistical basis, and correlation with the degree of unsaturation. Renew. Energy 2018, 126, 403-419. [CrossRef]

75. Yaşar, F. Comparision of fuel properties of biodiesel fuels produced from different oils to determine the most suitable feedstock type. Fuel 2020, 264, 2-6. [CrossRef]

76. Barabas, I.; Todoru, I.A. Biodiesel Quality, Standards and Properties; Montero, G., Ed.; Technical Univeraity of Cluj-Napoca: Cluj-Napoca, Romania, 2011; pp. 1-28. ISBN 978-953-307-784-0. [CrossRef]

77. Al-Abdullah, M.H.; Kalghatgi, G.T.; Babiker, H. Flash points and volatility characteristics of gasoline/diesel blends. Fuel 2015, 153, 67-69. [CrossRef]

78. Senthil, R.; Silambarasan, R. Annona: A new biodiesel for diesel engine: A comparative experimental investigation. J. Energy Inst. 2015, 88, 459-469. [CrossRef]

79. Canesin, E.A.; de Oliveira, C.C.; Matsushita, M.; Felicidade Dias, L.; Reghiany Pedrão, M.; de Souza, N.E. Characterization of residual oils for biodiesel production. Electron. J. Biotechnol. 2014, 17, 39-45. [CrossRef]

80. Ghoreishi, S.M.; Moein, P. Biodiesel synthesis from waste vegetable oil via transesterification reaction in supercritical methanol. J. Supercrit. Fluids 2013, 76, 24-31. [CrossRef]

81. Palash, S.M.; Kalam, M.A.; Masjuki, H.H.; Masum, B.M.; Rizwanul Fattah, I.M.; Mofijur, M. Impacts of biodiesel combustion on NOx emissions and their reduction approaches. Renew. Sustain. Energy Rev. 2013, 23, 473-490. [CrossRef]

82. Sadeghzadeh, B. A review of zinc nutrition and plant breeding. J. Soil Sci. Plant Nutr. 2013, 13, 907-927. [CrossRef]

83. Avila Orozco, F.D.; Kovachev, N.; Aguirre Pastor, M.Á.; Domini, C.E.; Fernández Band, B.S.; Hernández, A.C. Analysis of metals and phosphorus in biodiesel B100 from different feedstock using a Flow Blurring in inductively coupled plasma-optical emission spectrometry. Anal. Chim. Acta. 2014, 827, 15-21. [CrossRef] [PubMed]

84. Lyra, F.H.; Tereza, M.; Dias, W.; Brandão, G.P.; Pessoa, H.M.; de Castro, E.V. Determination of Na, K, Ca and Mg in biodiesel samples by flame atomic absorption spectrometry (FAAS) using microemulsion as sample preparation. Microchem. J. 2010, 96, 180-185. [CrossRef]

85. Vieira, M.A.; Castro, C.; Ara, R. Determination of As in Vegetable Oil and Biodiesel by Graphite Furnace Atomic Absorption Spectrometry. Energy Fuels 2009, 23, 5942-5946. [CrossRef]

86. Hoekman, S.K.; Broch, A.; Robbins, C.; Ceniceros, E.; Natarajan, M. Review of biodiesel composition, properties, and specifications. Renew. Sustain. Energy Rev. 2012, 16, 143-169. [CrossRef]

87. Iqbal, J.; Carney, W.A.; Lacaze, S.; Theegala, C.S. Metals Determination in Biodiesel (B100) by ICP-OES with Microwave Assisted Acid Digestion. Open Anal. Chem. J. 2010, 4, 18-26. [CrossRef]

88. Woods, G.D.; Fryer, F.I. Direct elemental analysis of biodiesel by inductively coupled plasma-mass spectrometry. Anal. Bioanal. Chem. 2007, 389, 753-761. [CrossRef] [PubMed]

89. Szyczewski, P.; Frankowski, M.; Zioła-Frankowska, A.; Siepak, J.; Szyczewski, T.; Piotrowski, P.; Pillay, A.E.; Elkadi, M.; Fok, S.C.; Stephen, S.; et al. Metals Determination in Biodiesel (B100) by ICP-OES with Microwave Assisted Acid Digestion. Microchem. J. 2010, 96, 18121-18129. [CrossRef]

90. Henrique Lyra, F.; Weitzel Dias Carneiro, M.T.; Pedrini Brandão, G.; Moura Pessoa, H.; Ribeiro De Castro, E.V. Direct determination of phosphorus in biodiesel samples by graphite furnace atomic absorption spectrometry using a solid sampling accessory. J. Anal. At. Spectrom. 2009, 24, 1262-1266. [CrossRef]

91. Ramadhas, A.S.; Jayaraj, S.; Muraleedharan, C. Biodiesel: Production and Properties; The Royal Society of Chemistry: Cambridge, UK, 2016; pp. 41-80. ISBN 978-1-84973-470-7.

92. de Goede, S.; Wilken, C.; Ajam, M.; Roets, P.; Engelbrecht, P.; Woolard, C. A Comparison of the Stability Performance of Blends of Paraffinic Diesel and Petroleum-Derived Diesel, with RME Biodiesel Using Laboratory Stability Measurement Techniques. J. Fuels 2015, 2015, 528497. [CrossRef]

93. Zuleta, E.C.; Baena, L.; Rios, L.A.; Calderón, J.A. The oxidative stability of biodiesel and its impact on the deterioration of metallic and polymeric materials: A review. J. Braz. Chem. Soc. 2012, 23, 2159-2175. [CrossRef]

94. Qiu, F.; Li, Y.; Yang, D.; Li, X.; Sun, P. Biodiesel production from mixed soybean oil and rapeseed oil. Appl. Energy 2011, 88, 2050-2055. [CrossRef]

95. Komariah, L.N.; Dewi, T.K.; Ramayanti, C. Study on corrosion behavior of storage tanks filled with biodiesel and the blends. IOP Conf. Ser. Mater. Sci. Eng. 2019, 543, 1-7. [CrossRef]

96. Yeşilyurt, M.K.; Öner, İ.V.; Yılmaz, E.Ç. Biodiesel Induced Corrosion and Degradation: A Review. Pamukkale Univ. J. Eng. Sci. 2019, 25, 60-70. [CrossRef]

97. Chaves, E.S.; José, E.; Araujo, R.G.O.; Vladimir, J.; Lúcia, V.; Frescura, A.; Curtius, A.J. Metals and phosphorus determination in vegetable seeds used in the production of biodiesel by ICP OES and ICP-MS. Microchem. J. 2010, 96, 71-76. [CrossRef] 
98. Kivevele, T. Storage and thermal stability of biodiesel produced from manketti nut oil of Southern Africa origin with the influence of metal contaminants and antioxidants. SN Appl. Sci. 2020, 2, 930. [CrossRef]

99. Jain, S.; Sharma, M.P. Effect of metal contents on oxidation stability of biodiesel/diesel blends. Fuel 2014, 116, 14-18. [CrossRef]

100. Shiotani, H.; Goto, S. Studies of fuel properties and oxidation stability of biodiesel fuel. SAE Tech. Pap. 2007, 116, 70-75. [CrossRef]

101. Knothe, G.; Steidley, K.R. The effect of metals and metal oxides on biodiesel oxidative stability from promotion to inhibition. Fuel Process. Technol. 2018, 177, 75-80. [CrossRef]

102. Sarin, A.; Arora, R.; Singh, N.P.; Sarin, R.; Sharma, M.; Malhotra, R.K. Effect of metal contaminants and antioxidants on the oxidation stability of the methyl ester of pongamia. JAOCS J. Am. Oil Chem. Soc. 2010, 87, 567-572. [CrossRef]

103. Baena, L.M.; Calderón, J.A. Effects of palm biodiesel and blends of biodiesel with organic acids on metals. Heliyon 2020, 6, 2-13. [CrossRef] [PubMed]

104. Sentanuhady, J.; Saputro, W.; Muflikhun, M.A. Metals and chemical compounds contaminants in diesel engine lubricant with B20 and B100 biofuels for long term operation. Sustain. Energy Technol. Assess. 2021, 45, 101161. [CrossRef]

105. Thangavelu, S.K.; Ahmed, A.S.; Ani, F.N. Impact of metals on corrosive behavior of biodiesel-diesel-ethanol (BDE) alternative fuel. Renew. Energy 2016, 94, 1-9. [CrossRef]

106. Hu, E.; Xu, Y.; Hu, X.; Pan, L.; Jiang, S. Corrosion behaviors of metals in biodiesel from rapeseed oil and methanol. Renew. Energy 2012, 37, 371-378. [CrossRef]

107. Nurul, L.; Arita, S.; Prianda, B.E.; Dewi, T.K. Engineering Sciences Technical assessment of biodiesel storage tank; A corrosion case study. J. King Saud Univ. Eng. Sci. 2021, 33, 1-6. [CrossRef]

108. Marinković, D.M.; Miladinović, M.R.; Avramović, J.M.; Krstić, I.B.; Stanković, M.V.; Stamenković, O.S.; Jovanović, D.M.; Veljković, V.B. Kinetic modeling and optimization of sunflower oil methanolysis catalyzed by spherically-shaped $\mathrm{CaO} / \Gamma-\mathrm{Al}_{2} \mathrm{O}_{3}$ catalyst. Energy Convers. Manag. 2018, 163, 122-133. [CrossRef]

109. Zabeti, M.; Daud, W.M.A.W.; Aroua, M.K. Optimization of the activity of $\mathrm{CaO} / \mathrm{Al}_{2} \mathrm{O}_{3}$ catalyst for biodiesel production using response surface methodology. Appl. Catal. A Gen. 2009, 366, 154-159. [CrossRef] 